\title{
Economic Development of an Area Burdened by the Surface Mining of Brown Coal, with Regard to the Principle of Sustainable Development
}

\author{
Petr Vráblík, Jaroslava Vráblíková, Eliška Wildová \\ Department of Natural Sciences, Faculty of Environment, J. E. Purkyně University in Ústí nad Labem, \\ Ústí nad Labem, Čech \\ Email: Wildova.Eliska@gmail.com
}

How to cite this paper: Vráblík, P., Vráblíková, J. and Wildová, E. (2017) Economic Development of an Area Burdened by the Surface Mining of Brown Coal, with Regard to the Principle of Sustainable Development. Modern Economy, 8, 1517-1532. https://doi.org/10.4236/me.2017.812101

Received: November 10, 2017 Accepted: December 11, 2017 Published: December 14, 2017

Copyright ( 2017 by authors and Scientific Research Publishing Inc. This work is licensed under the Creative Commons Attribution International License (CC BY 4.0).

http://creativecommons.org/licenses/by/4.0/

\begin{abstract}
The article deals with an analysis of the economic development of an area which has been burdened with the surface mining of brown coal over a long period. It is an area in the northern part of the Czech Republic (Most Basin). The contribution mainly deals with the economic perspective, which is closely linked to the region's social and environmental conditions. For the purposes of compiling the contribution, it was necessary to utilize materials relating to sustainable development and prepared statistical analyses together with the authors' practical experiences. The model area has an unemployment rate which is among the highest in the Czech Republic (8.2\%); however, it is the lowest in the last 2 years. The demographic situation contends with an ageing population and the migration of productive inhabitants inland in the direction of the capital. At the same time, there is a large proportion of socially disadvantaged people here. However, the geographic location enables cross-border cooperation with neighboring Germany and, thanks partly to updated infrastructure, a better connection is possible. GDP is currently at the level of CZK 275,214 (EUR 10,089). It has increased compared to previous years. The region's potential lies mainly in new recreational areas, which will be created within the scope of reclamation after mining, and which will strengthen tourism and the service sector. After mining ends, around 2055, the transition to a renewable energy source will mean a further investment. Despite the negative image of the area of interest, particularly in terms of pollution as a result of mining, it is a region with the potential for sustainable economic development.
\end{abstract}

\section{Keywords}

Ecological Economics, Sustainable Development, Coal Mining, North 
Bohemia

\section{Introduction}

The area of interest, which comprises the districts of Chomutov, Most, Teplice, and Ústí nad Labem (Figure 1) has been significantly affected by intensive mining and industrial activity for almost 200 years. Under the influence of mining and energy industry activities, the burden on the landscape gradually increased. The Podkrušnohoří Basin region was deliberately designated for the interests of the increasing mining of brown coal, whose combustion became a basic energy source for the material- and energy-hungry Czech economy. The territory of the model area, which is the subject of research by the Faculty of Environment of the Jan Evangelista Purkyně University in Ústí nad Labem, takes up an area of 2276 $\mathrm{km}^{2}$ and is home to 486 thousand inhabitants. The area is a typical industrial region which, in the late 1980s, thanks to the large-scale method of brown coal mining, was part of the "Black Triangle", then referred to as the most devastated area in Central Europe. To date, as a consequence of the transformation of the Czech economy, significant changes have taken place in the area of North Bohemia-a decline in mining and industrial manufacture, and a reduction in the intensity of agricultural production, which brings with it other specific regional disparities, i.e. social and economic differences.

From its beginnings in 1850 until the present day, open-cast brown coal mining has affected an area of approximately $250 \mathrm{~km}^{2}$, reaching its peak with a volume of almost 70 million $\mathrm{t} /$ year in the 1980s (Figure 2). In 2016, mining in the North Bohemian Brown Coal District reached 31.07 million tons, and production on this territory under the Ore Mountains is carried out by Czechoslovak Army, Vršany, Libouš, and Bílina Quarries. According to current plans, given a

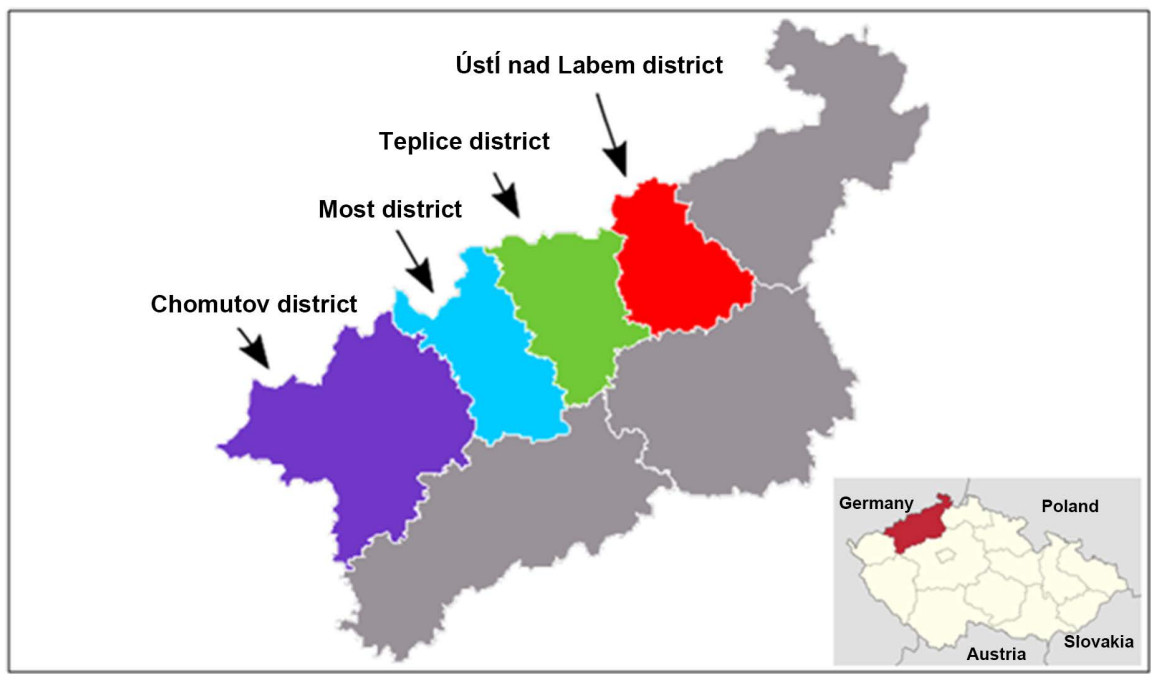

Figure 1. Administrative division of the region, with an illustration of the model area [1]. 


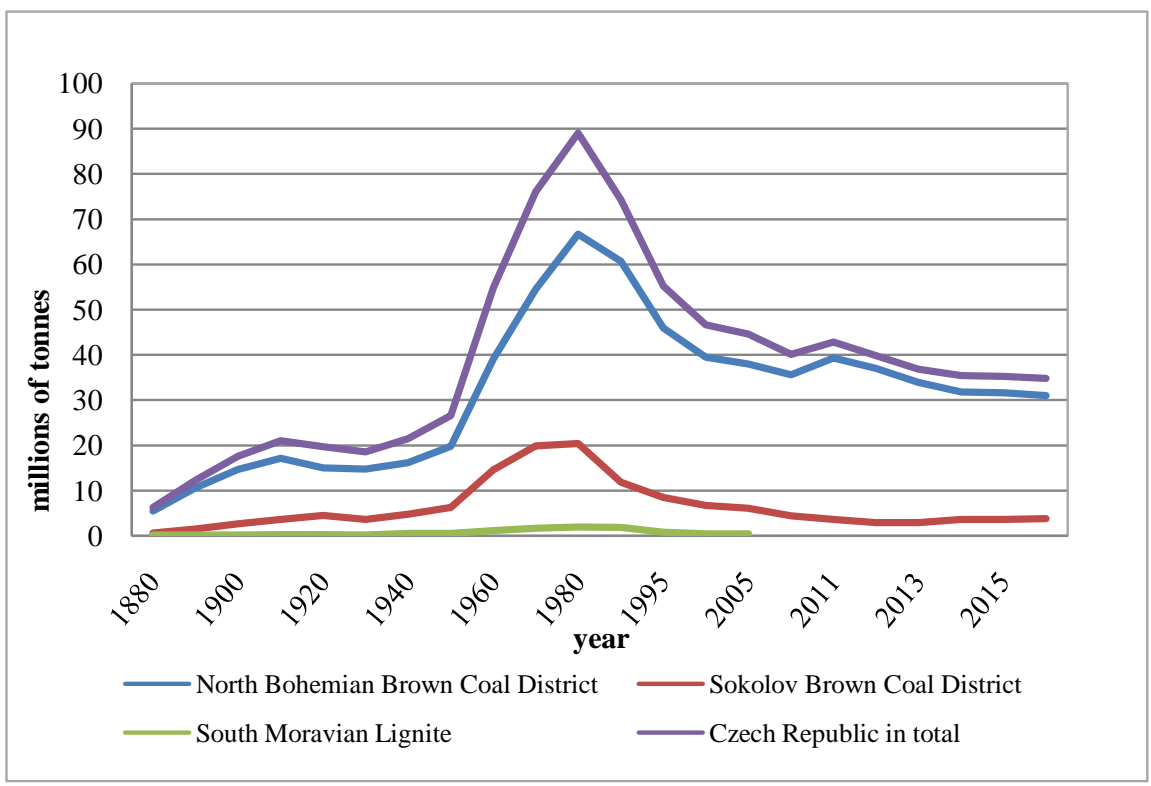

Figure 2. Historical development of brown coal mining in the Czech Republic since 1880. Authors' own adaptation from Mining Yearbook 2016 [3].

similar annual mining volume and in compliance with the existing limits in the Czechoslovak Army Quarry, mining in the North Bohemian Brown Coal District should end between 2050 and 2055. This will be done by mining the last of the coal supplies in the Vršany Quarry in the Slatinice extraction area and the Bílina Quarry, whose continuation beyond the originally stipulated limits was decided on by the government in October 2015 by Government resolution No. 827 [2].

The economic development of the model area is still strongly influenced by ongoing mining activity, and local industrial activities are to a greater or lesser extent connected with the mining, transport, combustion, or other processing of brown coal. The economic subjects are also focusing on smoothing over the consequences of anthropogenic activities connected with mining-reclamation, restoration, and resocialization [4]. In particular, the health impacts connected with the dustiness of the mines and with the combustion of coal affected the region's demographic curve in the $80 \mathrm{~s}$ and $90 \mathrm{~s}$, as the increased occurrence of $\mathrm{SO}_{2}$ and $\mathrm{NOx}$ in the air caused a number of lung diseases. Today, thanks to new technology, these impacts have been eliminated, but this region still has the highest occurrence of lung diseases in the Czech Republic. And from an economic perspective, the unemployment rate in the area of interest is still among the highest. Given the gradual decline of mining, investment is shifting to other sectors - recreation, agriculture, etc. Thanks to the subsequent reclamation, there is a high probability that the situation here will improve to a certain extent, but the demographic and social development does not indicate a significant improvement. The contribution deals with the link between economic development and the sustainable development of an anthropogenically burdened region. It 
summarizes documents which are closely related to the region's economic development, with regard to the economic pillar. At the same time, it presents the specific economic, social, and environmental problems which the model area is facing, and proposes possible solutions. Although the contribution deals with the economic, or more precisely the business development of the model area, the social and environmental situation is an essential part of the analyses.

\section{Materials and Methods}

The model area is part of a larger unit, the Ústí nad Labem Region, which comprises a total of seven districts. Apart from those which are part of the area of interest (Chomutov, Most, Teplice, and Ústí nad Labem), it also includes the districts of Litoměřice, Děćín, and Louny. The economic analyses of the region which is affected by mining are part of a project which is being dealt with by the Faculty of Environment of the Jan Evangelista Purkyně University. The main issue addressed by the project is sustainable management in an anthropogenically burdened region. The main document that was essential for the preparation of individual economic analyses was the Statistical Yearbook of the Ústí nad Labem Region 2016 [5]. This publication presents a structure-unified content and follows the national Statistical Yearbook of the Czech Republic, which is compiled at the headquarters of the Czech Statistical Office (CZSO). State statistical surveys are basic sources for the published data. Besides data sources of the Czech Statistical Office, available data from other public authorities were also used, especially from the Ministry of Labour and Social Affairs, Ministry of Finance, Ministry of the Interior, Ministry of Education, Youth, and Sports, Ministry of Health, Institute of Health Information and Statistics of the Czech Republic, and the Ministry of Transport. A vast portion of the data published is kept in the regional databases of the CZSO-KROK (data on regions and districts) and MOS (statistics of towns and municipalities), and in long-term time series. The data given in the Yearbook are valid as at 15 December 2016 and update the data and estimates published before.

The data showing the size and structure of the population are derived from population censuses, which are followed by annual statistical balances of data on births, marriages, divorces, deaths, and migration. Unless otherwise stated, statistical reports from registries are the data sources. Since 2011, data on the population size and structure follow the final results of the 2011 Population and Housing Census as at 26 March 2011; they are not comparable with the data for the previous years. All data refer to the population permanently resident on the given territory, irrespective of their citizenship.

Regional accounts, the most important source of regional macroeconomic indicators, are a regional analogy to national accounts. They result from annual national accounts compiled for the Czech Republic; as for the methodology they correspond to the European System of Accounts published in 2010 (ESA 2010) [6] and consistently observe rules and recommendations valid for Member 
States of the European Union, which means that they are comparable to them harmonized. In accordance with the ESA 2010 methodology indicators are surveyed by a workplace method, which means that indicators for enterprises are allocated to regions according to the real location of workplace of a unit. Gross value added for multi-regional organizations is allocated based on wages paid in individual regions. Indicators of household accounts are related to the place of residence of the households. Following macroeconomic indicators were chosen in order to determine economic situation of the area.

Gross domestic product (GDP) is a key indicator of the development of the economy. It is a set of values added of individual institutional sectors or individual industries in activities considered by the ESA to be productive (i.e. including both market and non-market services) and net taxes on products (it is thus expressed in purchaser prices). From the point of view of use, the GDP is equal to the sum of final consumption (of households, general government, and non-profit institutions serving households), gross capital formation (fixed capital and balance of inventories and acquisitions less disposals of valuables), and the external trade balance.

Gross value added (GVA) is the sum of values added of individual industries (i.e. GDP excluding net taxes on products, which cannot be divided among individual industries).

Gross fixed capital formation (GFCF) includes the value of acquisition of both tangible and intangible fixed assets (purchased, taken over free of charge or produced by own activities), deducted by the value of its sale and the value of assets handed over free of charge. It also includes acquisition in the form of financial leasing. The target of the acquisition is always to use the fixed assets for productive activity including housing in the dwelling of its owner. Only assets used in production for a period longer than one year are fixed capital. It includes also e.g. equipment for military purposes, research and development expenditure and the like.

Net disposable income of households is an amount that households can give to final consumption, savings in the form of financial assets, and to accumulation of tangible and intangible assets. Disposable income results from the generation and distribution of income and it is the balancing item of the secondary distribution of income account.

For the needs of the international comparison, selected indicators are converted to euro currency unit.

Another primary document was the Sustainable development strategy of the Ústí nad Labem Region 2006-2020 [7]. The document includes economic, social, environmental pillar and governance, which is seen as a place where sustainable development takes place. It is based on the current situation in the region. Qualification and quantification of priorities and strategic objectives is related to 2005. The document is processed according to Anglo-American planning model with small modifications and adaptation according to regional conditions. The methodical approach chosen was tested and innovated in the conditions of the 
Czech Republic and the whole of Central Europe. Document is based on data and information obtained by official statistical institutes or organizations authorized to collect and evaluate data. An expert working group participated in the elaboration of the document that was discussed with stakeholders and the public. The views of the public and experts based on the social situation of the Ustí region were reflected in the document through the results of sociological surveys. A SWOT analysis of Ústí region was compiled within the development strategy. It is a universal analytical technique used to evaluate internal and external factors which affect the success of an organization or a specific plan (for example a new product or service). The SWOT analysis is most frequently used as a situational analysis within the scope of strategic management and marketing. The author of the SWOT analysis is Albert Humphrey, who proposed it in the 1960s (Table 1). SWOT is an acronym of the initials of the individual factors: $\mathrm{S}=$ Strengths, $\mathrm{W}=$ Weaknesses, $\mathrm{O}=$ Opportunities, $\mathrm{T}=$ Threats [8].

The method used when writing the contribution was the detailed study of these materials and the connections between them, combined with the practical and professional experiences of the contribution's authors. The novelty of the methodology is in the summarization of available data in order to determine economic development of an area devastated by coal mining. The documents and methods used can serve as a guide for areas with this specific problematic to ensure sustainable development. Economical development of a territory affected by any kind of mining is affected also from social and environmental point of view and follow-up reclamation processes are dependent on such studies in order to choose the best way of restoration.

\section{Results and Discussion}

\subsection{Demographic Situation}

In order to evaluate the region's economic development, it is essential to analyse the demographic situation. We have processed the current data from the Statistical yearbook of the Ústí nad Labem region [5]. At present, the model area in question shows a number of more or less distinct (inter)regional disparities compared to its surroundings which affect both current development and quality of life. It is an area with a highly dense population which is concentrated in cities.

The basin region has become an important area for immigration, where the number of inhabitants in cities and villages has increased 2- to 4-fold during a

Table 1. General description of SWOT analysis [9].

\begin{tabular}{cccc}
\hline & & \multicolumn{2}{c}{ Factors } \\
\cline { 3 - 4 } & & Positive & Negative \\
\hline \multirow{2}{*}{ Influences } & Internal & $\mathrm{S}$ & $\mathrm{W}$ \\
& & Strengths & Weaknesses \\
& External & $\mathrm{O}$ & $\mathrm{T}$ \\
& & Opportunities & Threats \\
\hline
\end{tabular}


relatively short period. For the entire 20th century, the population in the model area was considerably more dense (by approximately 66\%) than the average in the Czech Republic.

At present, over 485 thousand inhabitants live in the model area, which is approximately $60 \%$ of the population of the Ústí nad Labem Region. Compared to 2010 , the number of inhabitants in the monitored area has decreased by almost 10,000 . The population density here is currently 213 inhabitants per $\mathrm{km}^{2}$, which considerably exceeds the average for the region (154 inhabitants $/ \mathrm{km}^{2}$ ) as well as for the Czech Republic (134 inhabitants $/ \mathrm{km}^{2}$ ). In the district of Ustí nad Labem, which is also a regional city, 295 inhabitants live per $1 \mathrm{~km}^{2}$, which is the highest value in the model area.

When we look at the population status of the model Podkrušnohoři Region, we see that the highest population density over a long period has been in the Teplice district, where the number of inhabitants at the end of 2015 was 128,734. The second most populous district has-also over a long period-been Chomutov (124,335 inhabitants at the end of 2015). They are followed by the Ustí nad Labem and Most districts. The population density trend in these districts fluctuates in each one, with certain similarities. In the monitored time interval of 2000-2015, the population density of all the districts reached its maximum values in 2008-2010. In the Most and Chomutov districts, we note a decreasing trend in the number of inhabitants, while the Ustí nad Labem and Teplice districts have shown a certain stability of values in recent years (Figure 3).

During the monitored time period, the proportion of women in all the districts in question was slightly higher than that of men. The Chomutov district has long shown the largest proportion of men. The trends regarding the proportion of men in the population are not similar across the districts. However, during the past few years, the values of this indicator grew slightly for all the districts.

The ageing trend of the population is evident in all the districts in the model area. It is identical to the national and regional trend. It is best shown by the growing age index. This indicator expresses the number of persons aged 65 and over per 100 persons aged 0 - 14 (usually expressed in \%). The value of $100 \%$ was exceeded at a national level in 2006, while at a regional level and the level of most of the examined districts it was only exceeded in 2012 (Figure 4). Therefore, this means that the model area does not belong among the areas with the oldest populations. The smallest proportion of inhabitants of post-productive age has long been shown in the Chomutov district, with the largest proportion being in the Ústí nad Labem district. After 2009, the proportion of the population of pre-productive age began to grow slightly in all the monitored districts, with the greatest increase in the Ústí nad Labem district.

\subsection{Macroeconomic Indicators}

In 2014, the Ústí nad Labem Region accounted for 6.0\% of the GDP of the Czech Republic, with a decreasing trend from 2012 onwards. The Gross Fixed Capital 


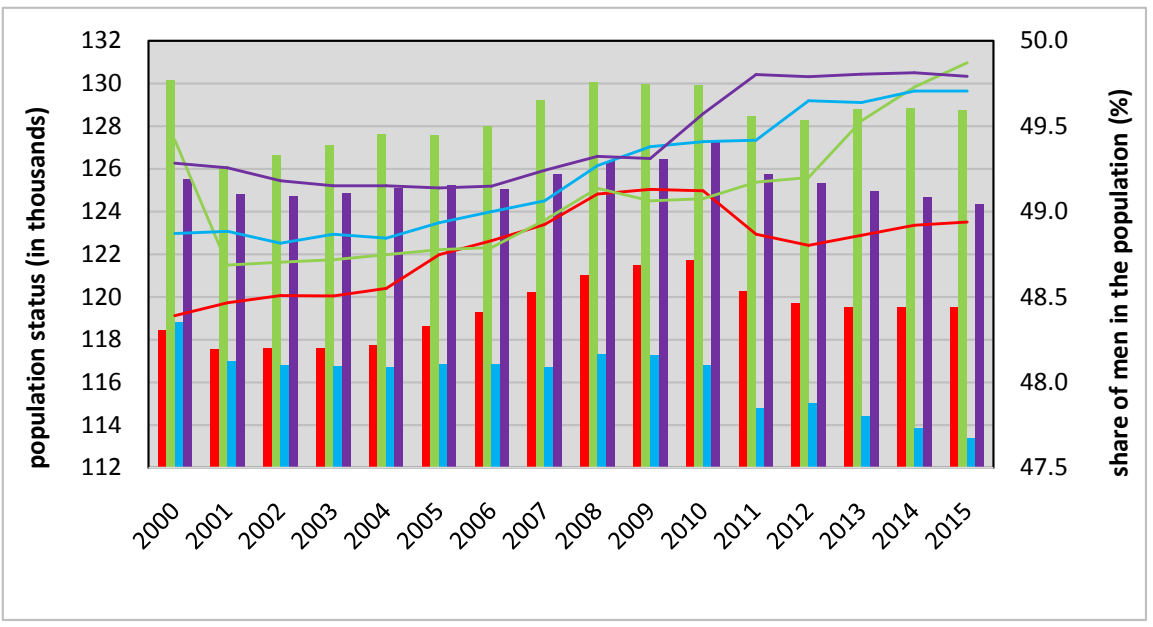

Figure 3. Population status in the model districts of Podkrušnohoří, and representation of men in the population (2000-2015) [4]. Note: The columns correspond to the population status, while the line graphs illustrate the representation of men.

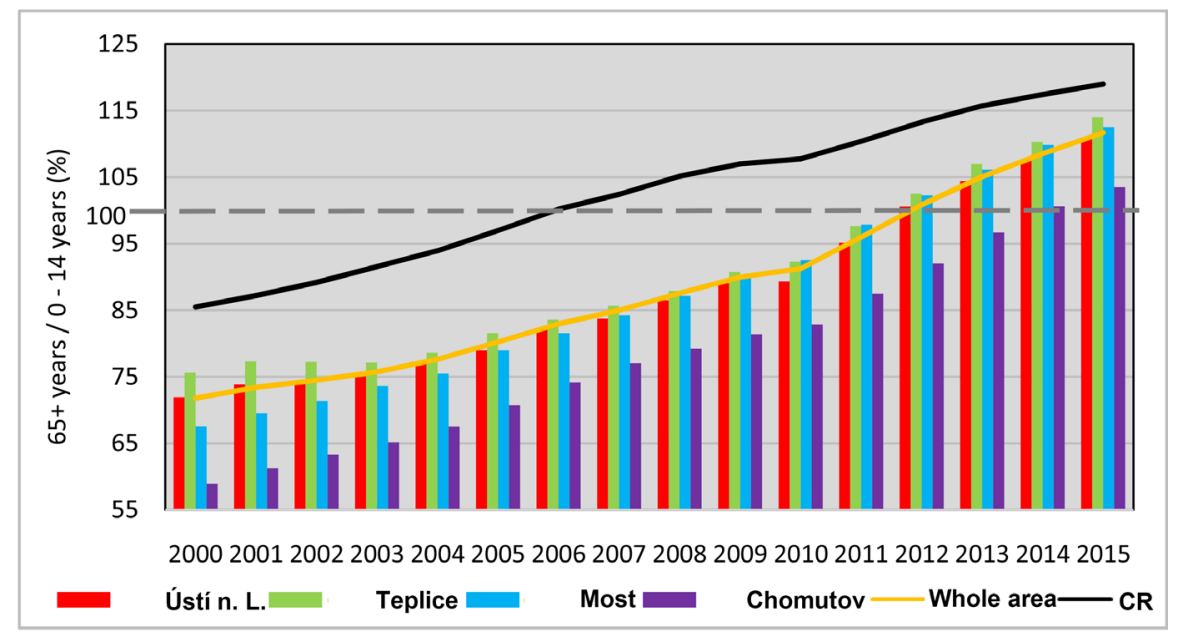

Figure 4. Age index in the model districts in the Podkrušnohoří Region, the Ústí nad Labem Region, and the Czech Republic (2000-2015) [4].

Formation (GFCF) indicator characterises the investment activities in the region. The region's share of the GFCF of the Czech Republic in 2013 was 7.0\%. The model area, and by extension the Ústí nad Labem Region, possesses a strategic advantage in its connection to Germany, and thanks to its dense infrastructure is one of the most connected regions to the European Union. The largest proportion of Gross Value Added in the region in 2014 was represented by services $(50.1 \%)$ followed by industry $(41.4 \%)$. Thanks to its mineral resources and direct connection to Germany, Ústí nad Labem is still a region of significant economic potential in the Czech Republic (Table 2).

\subsection{Unemployment in the Model Area}

The proportion of unemployed persons (number of accessible jobseekers aged 15 - 64 per number of inhabitants aged 15 - 64) was $4.90 \%$ at the end of 
Table 2. Macroeconomic indicators in the Ústí nad Labem Region 2013-2015 [5].

\begin{tabular}{|c|c|c|c|}
\hline & 2013 & 2014 & 2015 \\
\hline \multicolumn{4}{|l|}{ Gross Domestic Product (GDP) } \\
\hline in million CZK & 249,748 & 255,572 & 275,214 \\
\hline in million EUR & 9613 & 9281 & 10,089 \\
\hline in million PPS ${ }^{1)}$ & 14,346 & 14,814 & 16,052 \\
\hline $\begin{array}{c}\text { Development at constant prices, } \\
\text { previous year }=100\end{array}$ & 98.6 & 100.4 & 107.0 \\
\hline $\begin{array}{l}\text { The region's share of the GDP } \\
\text { of the Czech Republic (\%) }\end{array}$ & 6.1 & 5.9 & 6.0 \\
\hline \multicolumn{4}{|l|}{ Gross domestic product per 1 inhabitant } \\
\hline in $\mathrm{CZK}$ & 302,416 & 309,863 & 334,249 \\
\hline in EUR & 11,640 & 11,253 & 12,253 \\
\hline in $\mathrm{PPS}^{1)}$ & 17,371 & 17,961 & 19,495 \\
\hline Czech Republic average $=100$ & 77.6 & 75.6 & 77.4 \\
\hline EU average $28^{2)}$ in $P P S^{1)}=100$ & 65.1 & 65.1 & 67.5 \\
\hline \multicolumn{4}{|l|}{$\begin{array}{l}\text { Gross domestic product per } 1 \\
\text { person employed in CZK }\end{array}$} \\
\hline in $\mathrm{CZK}$ & 720,765 & 718,975 & 784,557 \\
\hline Czech Republic average $=100$ & 89.4 & 85.2 & 89.2 \\
\hline \multicolumn{4}{|l|}{ Gross Value Added (GVA) } \\
\hline in million CZK & 223,555 & 231,101 & 247,448 \\
\hline \multicolumn{4}{|l|}{ of which share of sector (\%) } \\
\hline Agriculture, forestry, and fishing & 2.2 & 2.2 & 2.1 \\
\hline Industry & 40.5 & 42.7 & 43.9 \\
\hline Construction & 6.6 & 6.3 & 6.5 \\
\hline Services & 50.7 & 48.8 & 47.5 \\
\hline \multicolumn{4}{|l|}{ Gross Fixed Capital Formation (GFCF) } \\
\hline in million CZK & 72,271 & 69,786 & \\
\hline in million EUR & 2782 & 2534 & \\
\hline $\begin{array}{c}\text { The region's share of the GFCF } \\
\text { of the Czech Republic (\%) }\end{array}$ & 7.0 & 6.4 & \\
\hline \multicolumn{4}{|c|}{ Gross Fixed Capital Formation per 1 inhabitant } \\
\hline in $\mathrm{CZK}$ & 87,512 & 84,611 & \\
\hline Czech Republic average $=100$ & 89.0 & 89.2 & \\
\hline \multicolumn{4}{|l|}{ Net Disposable Household Income (NDHI) } \\
\hline in million $\mathrm{CZK}$ & 143,091 & 144,972 & 150,644 \\
\hline in million EUR & 5508 & 5265 & 5522 \\
\hline $\begin{array}{l}\text { The region's share of the NDHI } \\
\text { of the Czech Republic (\%) }\end{array}$ & 6.9 & 6.7 & 6.8 \\
\hline \multicolumn{4}{|c|}{ Net Disposable Household Income per 1 inhabitant } \\
\hline in $\mathrm{CZK}$ & 173,267 & 175,769 & 182,958 \\
\hline Czech Republic average $=100$ & 87.4 & 85.7 & 86.5 \\
\hline
\end{tabular}

${ }^{1)}$ : PPS: Purchasing Power Standard; ${ }^{2)}$ : EU28: the 28 EU Member States. 
November for the entire Czech Republic, and 7.6\% for the Ústí nad Labem Region. Inter-regionally, the Ústí nad Labem Region has long shown the largest proportion of unemployed persons. As of 30/11/2016, the largest proportion of unemployed persons in the model area was in the Mostecko Region-10.0\%. Over the last month, the proportion of unemployed persons decreased in almost all the districts in the region. The most significant decrease was recorded in the Teplice Region (6.3\%). The smallest proportion of unemployed persons was recorded in 2008 (Figure 5).

At the end of November 2016, employment offices in the Ústí nad Labem Region recorded 43,717 jobseekers, with a total of 27,831 persons in the model area. The largest number of jobseekers is in the Chomutov district (7198 persons). Since the start of the year there has been a gradual decrease of the number of jobseekers in the model area, in the Ústí nad Labem Region, and nationwide. The largest decrease in the number of jobseekers, of 1503 persons, was recorded in the Ustí nad Labem district. A significant difference in the number of jobseekers was also recorded in the Ústí nad Labem district in comparison with the same month in 2015 when 1462 more people were looking for work there.

\subsection{Analysis of the Region's Economic Development with Regard to Sustainable Development}

In 2004, the Ústí nad Labem Region registered for the project "Support during the Preparation of a Sustainable Development Strategy in Selected Regions of the Czech Republic", whose scope includes the pilot processing of the presented Sustainable Development Strategy for the Ústí nad Labem Region 2006-2020 (hereinafter the "SDSÚR"). This strategy aims to set the framework for the region's long-term development, which will apply the principles of the sustainable development concept and will be in accordance with the human sustainable development mandate, and in the context of the sustainable development strategy

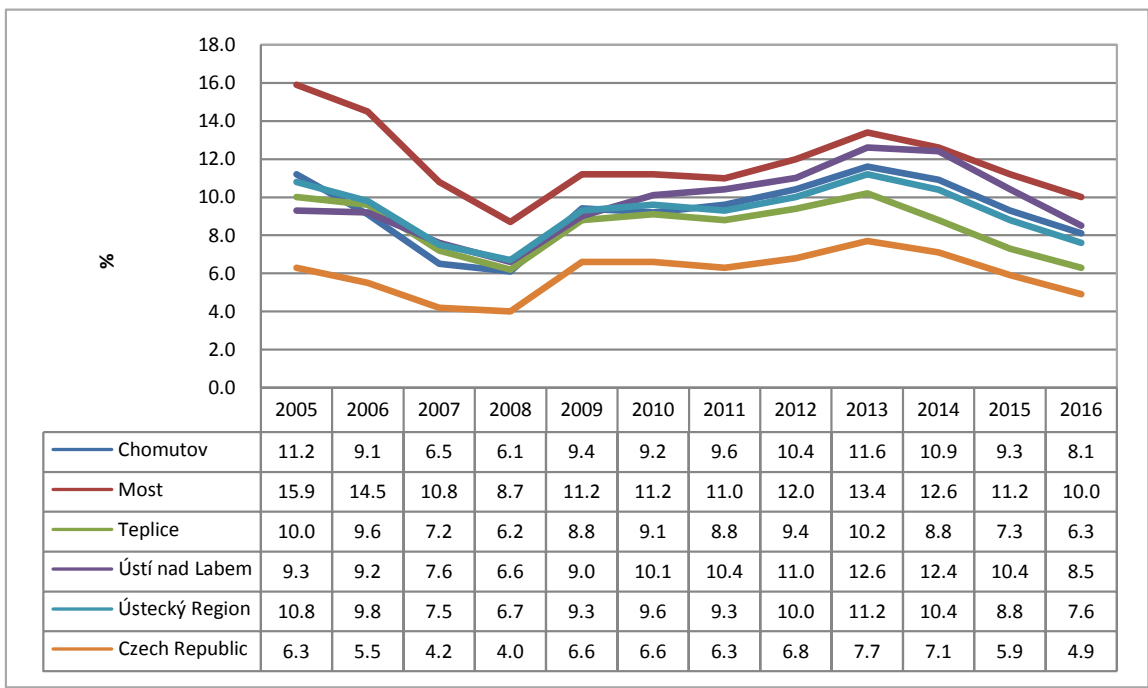

Figure 5. Development of the proportion of unemployed persons in the model area for November 2005-2016 [10]. 
of the Czech Republic [11]. Sustainable development is a European Union horizontal topic. The SDSÚR includes the economic, social, and environmental pillars, as well as the administration of public affairs, which is perceived as the space in which sustainable development takes place. It is based on the region's existing situation. In order to fulfill the main objectives of the institutional securing of sustainable development at a regional level, the Ústí nad Labem Regional Council established the Regional Development and Tourism Committee as its initiating and advisory body [6].

The following section describes results of the study concerning the public opinion of the inhabitants of the Ustí nad Labem Region within the scope of sociological research about sustainable development. In general, the inhabitants of the region regard the following problems as being the most serious:

\section{1) The area of economic development}

- Do not support mining and heavy industry in the future; give preference to tourism and the service sector.

- Make more use of the vicinity of the German border for an inflow of funds into the region.

- Requalification of the workforce, and good quality infrastructure.

- Reduce unemployment in the region by supporting new entrepreneurial activity.

- Investment in road reconstruction and improving the quality of motorways.

2) Socio-cultural area

- Improve the quality and availability of specialized doctors, and medical spa and rehabilitation services.

- Support the prevention of socio-pathological phenomena.

- Improve the integration of minority groups into society.

- Increase the number of completed new apartments, and restore old housing stock.

- Improve the quality of education, and increase the number of leisure activities.

\section{3) Environmental area}

- Support the expansion of special protection areas in the Ústí nad Labem Region.

- Investment in environmental protection, particularly air and landscape protection.

- Reduce noise level and improve air quality in connection with traffic.

- Improve the accessibility and increase the number of containers for recycling.

\subsection{SWOT Analysis of the Ústí nad Labem Region in Terms of the Economic Pillar of Sustainable Development}

The SWOT analysis was made within the Sustainable development strategy of the Ústí nad Labem region 2006-2020 and the results can be summarized as follows. 
Strengths:

- The region's advantageous geographical location (enabling cross-border cooperation with regions in Germany; influencing the proportion of foreign visitors who prefer multi-day tourism);

- presence of part IV. Berlin-Prague-Brno-Bratislava-Budapest-Sofia-Istanbul Trans-European multimodal corridor (D8 motorway; 090/815 railway line; Elbe waterway);

- dense regional road and rail network;

- good transport links among important regional centres;

- tradition of qualification for industrial manufacture (chemical, mining, energy, and glass-making industries);

- significant mineral reserves;

- sufficient and available labour force;

- diverse tourist potential of the region (large proportion of protected areas in the north-east part of the region; spa centres; winter sport complexes). Weaknesses:

- Persistence of the region's negative image;

- strong focus of the economy on industrial sectors with high material demands;

- small number of small and medium-sized enterprises which have been prospering over a long period;

- low proactivity by companies and enterprises in the region during the creation of a cluster system;

- high unemployment level, and imbalanced supply and demand in the labour market;

- large number of unused, derelict areas and buildings ("brownfields");

- poor technical condition of regional railway lines, II. and III. class roads and local routes;

- poor transport service in mountainous areas;

- low proportion of expenditure on science and research, and insufficiently developed information and communication infrastructure;

- inadequate basic and supplementary tourism infrastructure, including the absence of destination management and the appropriate services.

Opportunities:

- Increase of the region's economic growth as a result of the completion of the transformation of agriculture and industry, including the subsequent stabilisation of enterprises (increase of GDP/inhabitant per year in purchase power parity);

- increase of the number of stable economic subjects in the region as a result of support for local entrepreneurial activities;

- utilisation of the best available technology;

- stimulation of the inflow of foreign investment, particularly into sectors which produce the most modern technology (“Hi-Tech"); 
- preparation of quality developmental projects and effective utilisation of EU financial instruments;

- utilisation of the potential of eco-friendly tourism, including the possibility of eco agrotourism within the scope of the primary sector;

- the growing role of corporate social responsibility;

- "public-private partnership".

Risks:

- Reduction of the inflow of foreign capital, selection of unsuitable foreign investors and ineffective utilization of investments;

- growth in unemployment connected with the decline in heavy industry, energy industry, and mineral extraction;

- insufficient development of small and medium-sized enterprises in the region;

- outflow of highly qualified workforce;

- increase in passenger transport capacity, in particular private car transport, as a result of the "forced mobility of the inhabitants" caused by insufficient job opportunities in their place of residence;

- lower quality of tourist services and infrastructure compared to competing neighboring regions [7].

The problems of the economic development of the model area of Podkrušnohoří are partly related to climatic restrictions, which result in unsuitable conditions for agriculture. Nevertheless, after mining ends, the location may be suitable for a transition to wind energy, given the favourable meteorological situation [12]. The region's advantageous geographical location also enables cross-border cooperation with regions in Germany, but this is connected to the problem of the insufficient development of the technical infrastructure. However, this problem has been partly resolved thanks to the completion of the D8 motorway, which was opened in all directions on 20/09/2017 [13]. This resolved the transport interconnection of the Ore Mountains with the Capital City of Prague and with Germany. At the same time, the villages on the route between these cities are no longer endangered by intensive freight transport. However, the quality of II. and III. class roads, and local routes-including railway linesremains a problem. Another issue regarding the economic development of the model area is tourism, which is negatively affected by the ongoing mining. But the planned recultivations are a unique opportunity to build new recreational zones, especially water bodies, which are created within the scope of hydrological recultivations [14]. A particularly important aspect will be the construction of good quality recreational facilities, because the Ore Mountains are also visited by German citizens from Saxony. The most serious issue in the area of interest is unemployment, which is closely linked with the social situation in the entire Ústí nad Labem Region. The number of job opportunities is increasing, and unemployment has decreased considerably since 2014 [10], but it is still a region where a large proportion of unemployed persons is recorded due to a high concentration of inhabitants who misuse the Czech Republic's social system. The 
economic development of the Ore Mountains is also restricted by the protection of large areas for decisive sources of drinking water for the Ústí nad Labem Region and north-west Bohemia [7]. At the same time, the region must contend with distinct signs of demographic regression, an ageing population, and the departure of inhabitants for the inland. In the future, it would also be appropriate to develop eco-friendly agriculture and forestry. For harmonious regional development, it is important to preserve the balance among the social, economic, and environmental pillars, which are the basic concepts for sustainable development [11].

\section{Conclusions}

The model area of the Most Basin has long been affected by the surface mining of brown coal, which in the past brought about the considerable development of industry and job opportunities; after its decline, however, economic, social, and environmental problems began to appear. The contribution is based primarily on materials dealing with sustainable development, which will ensure suitable conditions for future generations. The demographic situation in the region must contend with an ageing population, and a reduction in the number of productive persons who could strengthen the economy. The main issue is unemployment, which, however, has improved from $12 \%$ to $8.2 \%$ since 2014 . Positive development is expected in the future, but modification of the social welfare system, which is being abused by some of the inhabitants of the Ústí nad Labem Region, is essential. Nevertheless, the region has the potential for economic development thanks to its advantageous location adjacent to the Free State of Saxony. The gradual addition of recultivated areas will lead to the creation of new recreational zones, which will help develop tourism and the service sector. Another opportunity for this area is its mineral reserves, though it is necessary to proceed with regard to sustainable development. Macroeconomic indicators show weak economic growth (GDP grew by almost CZK 20,000 compared to 2014). From an environmental perspective, the model area is one of the most polluted regions in the Czech Republic, but this situation is also improving. After the mining limits are reached around 2055, a transition to renewable energy sources will be necessary; these will provide new opportunities, and improve the region's economic development.

The novelty of contribution is the fact that areas devastated by coal mining may still have positive economical development and that reclamation and restoration processes could be a great chance how to make future economic development sustainable. At the same time, the contribution gives a guide whose documents and analysis should be made in order to describe economy of the chosen territory with respect to the sustainable development. This study can serve as a basis for future decision making process within the reclamation and restoration, because it summarizes strengths, weaknesses, opportunities and threats of the Ústí region. Future research should be focused on better implementation of sustainable development principles into social, economic and en- 
vironmental development of the area of interest. The biggest opportunity is transition to renewable resources of energy after the termination of coal mining which is planned in 2055. More researches should be concentrated on analyses of economic efficiency and environmental sustainability of individual resource according to the specific conditions of our research area (total costs, Environmental Impact Assessment, consumption coverage etc.). Regions affected by surface coal mining have complicated development, but they have a unique chance for improvement if the restoration and reclamation processes will be well controlled.

\section{Acknowledgements}

This article was supported by project QJ1520307 entitled "Sustainable Forms of Management in an Anthropogenically Burdened Region”. This project was realized with financial support from state budget resources through the KUS program, Ministry of Agriculture of the Czech Republic.

\section{References}

[1] Subrt, D. (2016) Administrative Division of the Region, with an Illustration of the Model Area. Report within the Project QJ1520307-Sustainable Forms of Management in an Anthropogenically Burdened Region, Faculty of Environment, J. E. University in Ústí nad Labem.

[2] Government of the Czech Republic (2015) Government Resolution of the CR No. 827-Resolution of the Further Progress of Territorially Ecological Limits of Brown Coal Mining in Northern Bohemia, Prague.

[3] The staff of the State Mining Authority (2017) Mining Yearbooks (2005-2016). The Czech Mining Authority and the Mining and Oil Industry Employers' Union, Ostrava.

[4] Vráblík, P., et al. (2017) Reclamation, Restoration and Resocialization of an Anthropogenically Affected Landscape as Tools of Sustainable Development. Conference Proceeding: Public Recreation and Landscape Protection-With Nature Hand in Hand?, Brno, 1-3 May 2017, 277-284.

[5] Regional Office of the Czech Statistical Office (2016) Statistical Yearbook of the Ústí nad Labem Region - Regional Statistics, Ústí nad Labem.

[6] European Comission (Eurostat) (2013) European System of Accounts (ESA 2010). European Union, Publications Office of the European Union, Luxembourg.

[7] Hrebík, S., et al. (2005) Sustainable Development Strategy of the Ústí nad Labem Region 2006-2020. Institute for Ecopolitics, Prague.

[8] Grasseová, M., et al. (2012) Analysis of the Business in the Hands of the Manager. 2nd Edition, BizBooks, Brno.

[9] Humphrey, A. (2005) SWOT Analysis for Management Consulting. SRI Alumni Newsletter. SRI International, United States.

[10] Czech Statistical Office (2016) Population Data-Unemployment. https://www.czso.cz/

[11] Government Office of the Czech Republic (2017) Czech Republic 2030-Strategic Framework. Department for Sustainable Development, Prague.

[12] Institute of Physics and Atmosphere of the Academy of Sciences of the Czech Re- 
public (2009) A Map of the Average Wind Speed Range at $100 \mathrm{~m}$ above the Surface. http://www.ufa.cas.cz/imgs/DLouka/vetrna_mapa.gif

[13] Czech Television (2017) The New Part of the D8 via the Central Bohemian Highlands Is Open for the First Time without Any Restrictions. http://www.ceskatelevize.cz/ct24/domaci

[14] Vráblík, P., et al. (2017) Recreational Potential of an Anthropogenically Affected Landscape in Northern Bohemia. Journal of Landscape Management, 8, 51-57. 